\title{
Steps toward Universalism in Immigration Policies: Canada and Germany
}

Dietrich Thränhardt RCIS Working Paper No. 2014/2 February 2014

\section{SERIES EDITOR}

Harald Bauder

Ryerson Centre for Immigration \& Settlement Ryerson University Jorgenson Hall, 620 350 Victoria Street, Toronto, ON M5B2K3 http://www.ryerson.ca/rcis 


\title{
RCIS Working Paper
}

No. $2014 / 2$

\section{Steps toward Universalism in Immigration Policies: Canada and Germany}

\author{
Dietrich Thränhardt
}

RYERSON CENTRE

for Immigration and Settlement

Series Editor: Harald Bauder

RCIS Working Papers present scholarly research of all disciplines on issues related to immigration and settlement. The purpose is to stimulate discussion and collect feedback. The views expressed by the author(s) do not necessarily reflect those of RCIS. For a complete list of RCIS publications, visit www.ryerson.ca/rcis

ISSN: 1929-9915

cc) (i) $\ominus$ Creative Commons Attribution-Noncommercial-No Derivative Works 2.5 EY NC No Canada License 


\begin{abstract}
Canada's points system was historically significant for its universalism, ending ethnic discrimination in the selection process for new immigrants. In spite of its appeal world-wide, however, it has not been successful in matching well-qualified migrants to good jobs, instead leading to "brain waste", as exemplified by academics driving taxis. To avoid this problem, Germany should not imitate Canada's points system, but instead Canada's easy naturalization, welcoming multiculturalism, and acceptance of immigrants in political life.

Germany has made important steps toward a universalist immigration system. It is part of the EU's open sphere, which enables every EU citizen to move freely. This sphere may be further widened in the coming years. Moreover, the EU Blue Card system enables anyone in the world to work in Germany, with only a minimum salary level as a condition. The EU's open sphere and Blue Card system are making important contributions to the establishment of an open world, a perspective that should be discussed in North America.
\end{abstract}

Keywords: points system, Germany, Canada, immigration, universalism, brain waste, EU, Blue Card, central planning, foreign students

\title{
1. The Liberal Dilemma
}

International human rights include the right to leave one's country, to emigrate, but they do not include the right to immigrate to a given country, despite globalization and today's intense trade, travel, services, and information networks. James Hollifield (1992) is often quoted on his description of a "liberal dilemma": the divergence of "economic liberalism" (with its border-crossing worldwide impetus) from "political liberalism" (with its nation-bound energy). Since national borders and national sovereignty seem to be so evident and prevailing, only a few books discuss the opening of borders and ask "Faut-il ouvrir les frontières?" (de Wenden, 1999). In the 1990s, Yasemin Soysal (1994) and David Jacobson (1996) argued that an emerging international human rights regime inspires states' actions, Jacobson pointing to international treaties and conventions, pacts implemented by national courts, and Soysal to an "international script" shaping actors' behavior and states' actions. Despite these hopes after the end of the Cold War, realities today are rather disappointing, and in American legal discourse there is even a strong principal of rejecting foreign examples. Moreover, much of the literature is only concerned with the realities, problems, and perspectives of Western countries without looking at the "rest of world". A recent study about borders describes the selective entry policies of "OECD countries", "Western states", or "liberal democracies", identifying the three as largely parallel (Mau et al., 2012). Many other studies are satisfied with a reference to the "Westphalian system" and sovereignty.

Such general discussions do not do justice to the varieties of immigration policies in Europe and North America. Some countries have made progress 
toward universalism, limiting or softening the discrimination that the world inherited from colonial times, which has been reshaped by today's economic inequalities between rich and poor countries. In this essay, I shall compare the Canadian and the German approaches. Both countries have made radical reforms to their immigration rules in the last decades, albeit quite differently. My frame of reference is rather unorthodox, defining universalism as a general opening of borders to potential immigrants all over the world. As often happens in immigration studies, gaps between the images of countries with the public discourse on the one hand and realities of immigration on the other can be detected, alongside misunderstandings and ironies, in international comparisons.

\section{Germans in Praise of Canada}

Canada is the admired model immigration country in Germany. From the ground breaking report of the Süssmuth Commission in 2001 (BMI 2004) to the report of the Berlin Institute in 2012 (Sievert/ Slupina/ Klingholz 2012), Canada has again and again been praised as the model to follow., The general mantra is, as the Commission chair and opposition politician Professor Rita Suessmuth put it, that "new immigrants should be selected on the basis of a points system, similar to that used in countries such as Canada" (BBC 2001).

The Canadian points system is described as a model of clarity, openness, multicultural enlightenment, and economic rationality, opposed to the selfimposed confusion of Germany's immigration policies that led to a "state crisis" in 1992, as Chancellor Helmut Kohl put it, and brought unwanted "immigration into the welfare system", as Chancellor Angela Merkel regularly criticised in her speeches (Merkel 2010). Former Bavarian minister Günther Beckstein used the slightly more aggressive formula "we need more immigrants who are of use to us and less who use us" ("mehr Zuwanderer, die uns nützen und weniger, die uns ausnützen"), pointing to the necessity for more economic rationality.

German free-marketeers are particularly eager to introduce Canada's points system. The Free Democrats, Germany's only devoted free market party, has had it in its platform for decades (FDP 2008), as has the leftist Green Party. The same holds for the main industry associations BDI and BDA. While it is somewhat ironic that the points system is clearly an example of a state-planned economy - anathema for free-marketeers in goods and services or in the financial markets - the system makes sense for businesses, since such a policy would bring abundant numbers of qualified people into the country, enlarge the supply of specialists, and make it easier to hire from a larger labour pool at lower wages. Moreover, new immigrants are usually credited for their economic dynamism, their wish to work hard to earn money to establish themselves, and their low resilience against exploitation, since they have yet to develop networks and are particularly dependent on their employers in the first years. 


\section{Canadian Universalism}

Canada has come a long way from its historic strict preference for Europeans and Prime Minister Macdonald's opinions about the "Aryan race", but this progress should not be confused with an open model (Triadafilopoulos 2012; Stasiukis/Abu-Laban 2004: 377). This change was, as Triadafilopoulos (2008) has explained in detail, caused by shifting world politics, and specifically by Canada's relations to the other members of the former British Empire and now Commonwealth. It was not conceived out of economic rationality. Prime Minister Pierre Trudeau and his associates formulated a new colour-blind policy of accepting everybody without regard to "race", creed, or culture. At the same time, Canada identified officially with "multiculturalism" - a way out of the dangerous Anglo-French divide that threatened Canada's very existence and coherence. The colour-blind points system was conceived as an alternative to the parochial British- and European-based migrant selection processes. Immigration would not be dependent on culture or origin but on objective human capital criteria like education, qualification, work experience, language skills, and age. This was also the high time of the belief in state planning and social engineering in Western societies.

The Trudeau government was successful in inventing and communicating a new, positive Canadian identity based on multiculturalism - understood as the equality of cultures, tolerance, and the common will to integrate into such a tolerant nation - just north of the race riots in the United States. Canadian philosophers, researchers and journalists have been active in promoting the message world-wide (Kymlicka 2004). Multiculturalism today is a kind of Canadian ideal export article, and Canada has been successful in promoting a positive image of efficiency cum multicultural tolerance throughout the world. Canadians have so successfully identified with the new positive approach that there has not been a major negative politicization of immigrants. This stands in stark contrast to other Western countries that embraced multiculturalism, like the Netherlands, which has suffered after its multicultural honeymoon from deep distress and pessimism about integration.

At the same time, the system promises technical efficiency and Cartesian clarity. Canada gets the best and brightest immigrants, with good exam marks and academic qualifications, speaking the country's languages English and French, in contrast to the much-perceived language problems in many European countries. The points system is a powerful symbol of openness and efficiency, of modernity and rationality. It is important for Canada's standing in the world, in opposition to European struggles and irrationalities and to the complex American policies of special definitions, denoted from A to Z, special interests, immense expulsion figures, and the building of a costly and cruel wall at the border to Mexico.

Moreover, the Canadian people feel that their government is in control of immigration. The points system has fulfilled quotas, assuring the public that the amount of immigration is planned, limited, and regulated. This translates into trust in government efficiency. As a result, there has been evident shock in the 
few cases of immigrants arriving spontaneously on Canadian shores, even when the numbers have been quite low compared to European experiences. It constitutes nation-wide agitation when a non-invited immigrant ship arrives in Canadian harbours. Canadians also reacted strongly to the reintroduction of visa requirements when a few Czech gypsies claimed asylum in Canada.

As "evidence of successful integration", both political and emotional, Phil Triadafilopoulos $(2006,2012)$ rightly points to high naturalization figures, a rise in the political participation of immigrants and the high subjective identification of Canadian immigrants with Canada as well with their own cultural background. In all these respects, Canada can be considered a world leader. Immigrants can naturalize after three years, former citizenships can be upheld, and immigrants do naturalize in high numbers. Canada has experienced a surge in political participation of immigrants in recent years, and it was symbolically important that a female immigrant from East Asia became Governor General of Canada. Immigrants identify with Canada about as much as Canadian-born people, and at the same time, they often identify with their cultural heritage. Canadian multiculturalism is conceived of as a gathering of people from all over the world, all contributing their cultural baggage while identifying with a country proud of its diversity. Thus, Canadian multiculturalism is an essentially unifying and integrative ideology. It differs from the understanding of multiculturalism that highlights the cultural differences between "us" and "them", which led to chancellor Merkel's remark in 2010 about multiculturalism having "utterly failed" in Germany, which made headlines world-wide and was seconded by France's Sarkozy and Britain's Cameron; this despite the fact that multiculturalism was never an official policy in Germany.

\section{Yet Canada Changes the System}

Canada has been successful with respect to the emotional, political, and social integration of new immigrants, and it was able to project a positive image of Canadian openness world-wide. Canada was also able to attract well-qualified immigrants, particularly a high percentage of academics.

However, the points system was less successful with respect to the placement of these well-qualified immigrants. Canada is a world master in "brain waste". Among OECD countries, over-qualification is particularly salient in Canada and has been rising between 2003/04 and 2009/10 (OECD 2012, $121 \mathrm{f}$., 131f.). The problem of immigrant academics working as taxi drivers and in other low-quality jobs has been on the Canadian agenda for years (O'Shea, 2009; Doomernik et al., 2009). The points system is not efficient in matching highly qualified immigrants to jobs. Studies in the United States have shown that family migration was more successful in integrating immigrants into the job market than qualification-based schemes (Jasso/Rosenzweig, 1995). In Canada itself, the wage gap between immigrants and the indigenous workforce has been widening. 
All these problems have been discussed openly for years. To solve them, the Canadian government provides integration programs for well-qualified immigrants. More radically, it has side-lined the points system and begun to recruit people directly to jobs (O'Shea 2009). Recently, it has also implemented a "Temporary Foreign Worker Program" with time-limited contracts for certain categories of work. Some worker categories are destined to be sent back to their home countries, and wages can be up to $15 \%$ less than posted (Canada 2013). Thus Canada deviated from the Trudeau immigration path, and in certain sectors, it now practices a rotation or "guest worker" policy that is often associated with the Germany of the 1960s. The difference, however, is that Germany kept the principle of equal pay, equal social and economic rights for everybody in accordance with EU rules, and did not enforce rotation. Typical for neo-liberal environments, Canada still cultivates quality immigration at the high end and identifies with the import of human capital. On the other hand, it accepts low-pay immigration, some with a prospect for permanent residence, others not.

In the international sphere, the fame of the Canadian model holds on. Journalists and even social scientists seem to be immune to changing facts and keep to the images they love. This is backed up by politicians and journalists who continue to tell the stories of Canadian success and German failure, embedded in the political cultures of both countries. Regrettably, it is not the welcoming spirit, the speedy naturalization, and the ease with which migrants can become Canadian politicians, ambassadors, and Governor Generals that impresses the German public, but rather the technicalities of a largely failed approach to selecting immigrants. This is connected to the nervous discussion in Europe about unwanted migrants and about the many qualified people moving to America. As the United States have a rather complex immigration system, it is the Canadian points system that is singled out positively. This betrays a fascination with a technical solution for complex political and economic problems.

\section{Deficits of Central Plan Systems}

In general, central state planning, centralized systems, and bureaucratic solutions have become unpopular these days. The points system contains the typical deficiencies of such systems. One is the definition problem. Difficult specifications and standards have to be brought under rather simple schemes. Other problems relate to the dynamics of the markets. Innovations happen quickly and are difficult to predict and tackle, particularly in advancing industries like IT and communications. The ups and downs of the business cycle do not fit into standard bureaucratic routines. It takes time to gather, analyze, and disseminate statistical data. It is also difficult to obtain reliable data on the number of specialists needed by a given industry, as employers have a strong vested interest in having access to a broad supply of potential employees. As a study on the IT industry in Germany has clearly shown, companies tend to claim much higher figures of specialists needed than they actually hire (Kolb, 2002). 
Networking factors are also important. Immigrants without contacts and relations do have difficulties reaching out to employers, particularly when they come from a foreign continent and a culture unknown to entrepreneurs. It is also difficult for employers to evaluate credentials from universities in countries they do not know. All these factors contribute to an employment gap for immigrants who arrive without a concrete job offer. "Brain waste" is the result.

\section{Criteria for Satisfactory Immigration Systems}

Canada deserves credit for having successfully promoted the idea that an immigration system should be universal and not discriminate on the grounds of ethnicity, "race", creed, gender, or origin. Even if Canada itself has to a certain extent lost trust in its own achievement, having gone back to rotation systems and introduced visas inside NAFTA against Mexicans, universal principles should be upheld in any satisfactory immigration system.

In addition, an immigration system should be efficient and transparent. It should avoid "brain waste" as much as possible. It should promote job chances for immigrants, empower people, and not make them dependent on employers or bureaucracies. Moreover, it should be open to positive immigration dynamics in the sense that successful immigrants should be able to promote further migration by extending invitations to other promising potential immigrants.

A satisfactory system should have safeguards against exploitation and undue dependence. It should be based on a reliable, accessible, and affordable legal system with equal rights for everybody.

\section{EU Citizenship and Mobility}

I propose that the EU citizenship and mobility system fulfils these requirements within the limits of the EU, that the area can be enlarged, and that the introduction of the "Blue Card" is a major step towards an open and transparent system world-wide.

Today, free movement is guaranteed in Europe, and the European Union even encourages and subsidizes mobility between member countries. Germany offers a special vocational training programme for young EU citizens. Free movement and the possibility to engage in employment or work independently is one of the four basic freedoms for EU citizens. EU citizens enjoy equal rights and freedoms in all EU countries, to such an extent that in some cases we find "reverse discrimination" - limitations that member states like Denmark, Britain, the Netherlands, and Germany impose on their own citizens but cannot be enforced against non-national EU citizens. Moreover, the EU Court in Luxembourg and the European Human Rights Court in Strasbourg provide efficient controls, assuring that EU standards and European human rights are upheld. One example is the abolition of the former British "virginity test", discriminating against Asian women. 
Qualifications and exams inside the EU are recognized mutually so as to enable people to work in their profession in other EU countries. With the exception of the British Isles, borders are open, including those of Switzerland and Norway. The EU has moved to recognize foreign credentials from non-EU "third countries", and Germany now has a law that guarantees a recognition process for every immigrant. It is, however, a lengthy and complex process to translate these legal rights into reality given that Germany has many regulatory bodies and powerful professional interest groups.

Whereas migration figures are rather low between the old member countries of the $\mathrm{EU}$, there is considerable migration from the new member states like Poland and Romania into the old member states. Migration streams depend on the economic attractions of member countries. There was considerable immigration to Southern Europe, Britain, and Ireland at the beginning of this century. After the economic crisis, migration has shifted to economically stable countries like Switzerland, Austria, and Germany. With very few exceptions, particularly in Britain, all of this internal migration did not cause any problems or alarm. EU citizens are increasingly considered as members of the European family. As migration is free in the EU, a re-Europeanization of migration can be observed (SVR 2013). We need only to look at the recent German figures (Table 1).

Table 1: Germany's Net Migration Balance 2012: Re-Europeanization

\begin{tabular}{|lc|lc|}
\hline \multicolumn{2}{|l|}{$\begin{array}{l}\text { Net Emigration: } \\
\text { most important countries }\end{array}$} & \multicolumn{2}{|l|}{ Net Immigration: } \\
\hline Switzerland & most important countries \\
Turkey & 4,948 & Poland & 69,900 \\
& & Romania & 45,812 \\
& Bulgaria & 25,121 \\
& Hungary & 26,208 \\
& Greece & 22,923 \\
& Italy & 21,716 \\
& Spain \\
\hline Total balance & +369.149 \\
German citizens & $-18,205$ \\
Foreigners & $+387,149$ \\
EU & $+273,433$ \\
\hline
\end{tabular}

Source: Statistisches Bundesamt 


\section{European Frontiers}

With the admission of Croatia into the EU in 2013, creating the EU 28, as well as several other South-East European states having now become visa-free, the Schengen Area can potentially be extended further.

More interesting in quantitative terms would be the enlargement of the free movement area towards the larger Eastern neighbours. Turkey has had an association with the EU (and its predecessor, the EEC) since 1963. As the figures in Table 1 make clear, there is no longer any immigration pressure from the Turkish side. Immigration numbers have fallen, and the emerging Turkish economy and thriving Istanbul are attractive to immigrants (Ette et al., 2013). Thus the visa requirements could be lifted without any problem.

Visa requirements could also be discontinued for Russians and Ukrainians, creating a larger European visa-free zone, or in Charles de Gaulle's famous words, l'Europe "de l'Atlantique à l'Oural" (charles-de-gaulle.org). Russia's population is declining sharply, and the same holds true for Ukraine. Thus there is no immigration pressure from the East.

However, there are perception problems in Germany as well as in other EU countries. Russia and Turkey are regarded as being different from Europe, as "the other". However, these feelings are not as strong as North American feelings towards Mexico and Latin America, and the EU has not backed Greece in building a wall at the Eastern border towards Turkey. Still, these negative emotions are an obstacle in the path to enlarging the area of free mobility to include more countries. Opening up towards Morocco and Tunisia would be even more difficult emotionally, but experts expect some progress in relation to Turkey and Russia in the coming years.

\section{The Universalist EU "Blue Card" and International Students}

Following the EU "Blue Card" directive, Germany has opened up its labour market. As of August 2012, all people world-wide can now work in Germany, provided they get a job offer of at least $€ 44,800$, or $€ 34,998$ for medical doctors and engineers. People can enter Germany to look for work. Students can take on part-time jobs, and foreigners graduating from a German university can take 18 months to look for work in Germany. In addition, there are arrangements for vocational training and attractive schemes for the self-employed.

By international comparison, the new system is open, transparent, and rights-based. It is destined to become an important gateway for immigrants. It fulfils the requirements listed above and has been evaluated positively by the OECD (2013). The OECD argues that Germany now has the "fewest restrictions on labour migration for highly skilled occupations, yet inflows continue to be relatively low... German employers can recruit from abroad for any job requiring university-level qualifications. Yet even employers declaring shortages have not done so, in part due to their insistence on German language skills and specific 
qualifications, in part due to a perception that international recruitment is complex and unreliable."

Looking into recent statistics, we see change arriving, albeit slowly. Results are apparent and immigration is getting more job-oriented, but much has yet to be done. German companies still have to learn how to recruit people from outside the country. Germany now has modern immigration laws, but mentalities still need to change. With the economic crisis, professionals from Southern Europe are moving to Germany, even if they are far less mobile than people from the new member countries.

The percentage of immigrants in Germany taking up jobs has gone up sharply for men in the last few years (Ette et al., 2013, 8). For immigrant women, the figures are still stagnant, pointing to another mentality problem among employers, particularly with respect to technical jobs.

The number of foreign students is also interesting. In 2008, Germany had 206,880 foreign students. Calculated per capita, Germany was less successful in attracting students than some English speaking counties, particularly Australia and Britain, but it was on the same level as Canada, and fared better that some other countries (Table 2). Since Britain is curtailing student numbers in 2013, there may be a chance for further enrolment in German universities. They may also be attractive because they are tuition-free. In 2013, foreign students paid $\$ 25,375$ for tuition in Australia, $\$ 25,226$ in the USA, $\$ 19,291$ in England, $\$ 18,474$ in Canada, $\$ 19,164$ in Japan, but only $635 \$$ in Germany (Foreign students 2013). On the other hand, German universities are under-funded. In 2012, 265,000 foreigners studied at German universities.

Table 2: Foreign Students in 2008: Countries Compared

\begin{tabular}{|l|c|c|}
\hline Country & $\begin{array}{l}\text { Number of Foreign } \\
\text { students in 2008 }\end{array}$ & $\begin{array}{l}\text { Foreign students per } \\
\text { capita of 20-24 year old } \\
\text { people in the country }\end{array}$ \\
\hline Austria & 230,640 & $15.9 \%$ \\
Britain & 341,790 & $8.4 \%$ \\
France & 243,440 & $6.1 \%$ \\
\hline Germany & 206,440 & $4.2 \%$ \\
Canada & 92,880 & $4.1 \%$ \\
USA & 624,470 & $2.8 \%$ \\
\hline Japan & 115,280 & $1.7 \%$ \\
Norway & 4,470 & $1.5 \%$ \\
\hline
\end{tabular}

Source: OECD 
It will take time and energy to change mentalities and to develop an open and welcoming atmosphere in Germany, or as the popular phrase goes today, a "welcoming culture". As in Canada, employers that have been lamenting the shortage of specialists in Germany for so long do not seem to be eager to look for immigrants and to take them in. Another problem is the slow-going bureaucratic practice at the German embassies after the visa scandal of 2005. There is still too much governmental bureaucracy, which hinders immigration. All in all, however, an open system is in place in the EU and beyond. New regulations have to be implemented, and routines have to be changed. The number of highly qualified immigrants has been rising in the past years, from 1,200 in 1998 to 21,100 in 2010.

\section{Mutual Learning}

Germany can still learn from Canada - not to imitate the points system but to practice openness, acceptance of cultural difference, a welcoming spirit, and easy naturalization. Canada can learn from Germany how to open borders and discontinue visa restrictions (even when this in difficult alongside the United States), to accept other countries on the same continent as equals, and to open up world-wide. As some Latin American countries are becoming more affluent and stable, visa requirements can be lifted, step by step. In a time when some of the world's largest democracies India and the United States along with SaudiArabia and Israel erect walls at their borders (Thränhardt, 2012), it is important to uphold the perspective of universal free movement. Step by step, the "liberal dilemma" of free markets and national borders can be solved, and a world where borders lose their separating function and people can move freely world-wide can be created.

\section{References}

Aybek, Can M., Christian Babka von Gostomski and Gaby Straßburger (2013) Heiratsmigration in die EU und nach Deutschland. Bevölkerungsforschung aktuell 2/2013: 12-22.

BBC (2001) Germany 'needs more immigrants', www.news.bbc.co.uk/2/hl/europe/1421533.stm

Beckstein (2000) Zitate von Günter Beckstein, CSU: www.gagaval.de/zitat/politik/HHC26.htm

BMI (Bundesministerium des Innern) (2004) Bericht der Unabhängigen Kommission "Zuwanderung, Berlin. www.bmi.bund.de/SharedDocs/Downloads/DE/Themen/Migration/ntegratio n/AsylZuwanderung/Zuwanderungsbericht pdf.html 
Brochmann, Grete (1999) The Mechanisms of Control, in: Grete Brochmann and Tomas Hammar (eds.), Mechanisms of Immigration Control. New York: Berg: 1-28.

Canada (2013) Human Resources and Skills Development Canada, Temporary Foreign Worker Program. www.hrsdc.gc.ac/eng/workplaceskills/foreign workers/almo/factsheet/shtml

Charles de Gaulle.org. Citations du général de Gaulle sur l'Europe (II). http://www.charles-de-gaulle.org/pages/l-homme/dossiers-thematiques/degaulle-et-le-monde/de-gaulle-et-Irsquoeurope/documents/citations-dugeneral-de-gaulle-sur-l-europe-ii.php

Doomernik, Jeroen, Rey Koslowski and Dietrich Thränhardt (2009) The Battle for the Brains. Why Immigration Policy Is not enough to Attract the Highly Skilled. Washington: The German Marshall Fund of the United States.

Doomernik, Jeroen, Rey Koslowski, Rey, Jonathan Lawrence, Rahsaan Maxwell, Ines Michalowski and, Dietrich Thränhardt (2009) No Shortcuts: Selective Migration and Integration. A Report to the Transatlantic Academy. Washington D. C.: Transatlantic Academy.

Ette, Andrea, Rabea Mundil-Schwarz, Leonore Sauer, Harun Sulak (2013) Ein neues Bild der Migration: Sozioökonomische Struktur und Arbeitsintegration von Neuzuwanderern aus Drittstaaten in Deutschland. Bevölkerungsforschung aktuell 2/2013: 2-11.

FDP 2008: Zuwanderung durch ein Punktesystem steuern - Fachkräftemangel wirksam bekämpfen. Bundestags-Drucksache 16/8492.

Foreign student fees in Canada competitive, HSBC finds. Canadian students say they're taking on more debt. CBC News. Posted: Aug 13, 2013 3:23 PM ET.

Hollifield, James F. (1992) Immigrants, Markets and States. The Political Economy of Past-War Europe. Cambridge: Harvard Univ. Press.

Jacobson, David (1996) Rights across Borders. Immigration and the Decline of Citizenship. Baltimore: Johns Hopkins Univ. Press.

Jasso, Guillermina and Mark Rosenzweig (1995) Do Immigrants Screened for Skills Do Better that Family Reunification Migrants? International Migration Review 29: 85-111.

Kolb, Holger (2002) Einwanderung und Einwanderungspolitik am Beispiel der deutschen „Green Card“, Münster.

Kymlicka, Will (2004) The Canadian Model of Diversity in Comparative Perspective. Eighth Standard Life Visiting Lecture. University of Edinburgh, www.cst.ed.ac.uk/docs/Kymlickalecture.doc

Mau, Steffen, Heike Brabandt, Lena Laube and Christof Roos (2012) Liberal States and the Freedom of Movement: Selective Borders, Unequal Mobility. Hondmills: PalgraveMacmillan. 
Merkel (2010) Wir brauchen keine Zuwanderung, die unsere Sozialsysteme belastet, in: CDU-Politik.de. Der unabhängige Blog zur Unionspolitik, 19.10.2010, http://www.cdu-politik.de/www/cdupolitik/wordpress314/2010/10/19/merkel-wir-brauchen-keine-zuwanderung-die-unseresozialsysteme-belastet

OECD (2012) Settling. OECD Indicators of Immigrant Integration 2012, Paris.

OECD (2013) Recruiting Immigrant Workers: Germany 2013, Paris.

O'Shea, Edwina (2009) Missing the Point(s): The Declining Fortunes of Canada's Economic Immigration Program. Washington: Transatlantic Academy.

Sievert, Stephan, Manuel Slupina and Rainer Klingholz (2012) Nach Punkten vorn: Was Deutschland von der Zuwanderungs- und Integrationspolitik Kanadas lernen kann. www. berlinInstitut.org/publikationen/studien/nachpunkten-vorn.html

Soysal, Yasemin (1994) Limits of Citizenship. Migrants and Postnational Membership in Europe. Chicago: Univ. of Chicago Press.

Stasiukis, Daiva, Yasmeen Abu-Laban (2004) Unequal Relations and the Struggle for Equality.Race and Ethnicity in Canadian Politics, in: Michael Whittington and Glen Williams (ed.), Canadian Politics in the $21^{\text {st }}$ Century. Sixth ed., Toronto: Thomas-Nelson.

SVR (2013) Jahresgutachten des Sachverständigenrats deutscher Stiftungen, Berlin.

Thränhardt, Dietrich (2012) Neue Grenzen in der Globalisierung. Über Grenzen. INDES 4/2012.

Triadafilopoulos, Triadafilos (2006) A Model for Europe? An Appraisal of Canadian Integration Policies, in: Karen Schönwälder, Sigrid Baringhorst and Uwe Hunger (eds.) Politische Steuerung von Integrationsprozessen. Intentionen und Wirkungen. Wiesbaden: VS, 79-94

Triadafilopoulos, Triadafilos (2012) Becoming Multicultural: Immigration and the Politics of Membership in Canada and Germany. Vancouver: Univ. of British Columbia Press.

Triadafilopoulos, Triadafilos (2008) Rethinking the Origins of the Points System, in: Axel Kreienbrink and Petra Bendel (eds.) Kanada und Deutschland: Der Umgang mit Migration und Integration im Vergleich. Nürnberg: BAMF, 2455.

Wihtol des Wenden, Catherine (1999) Faut-il ouvrir les frontières? Paris: Les Presses de Sciences. 